\title{
Identifikasi dan Perbandingan Kelimpahan Sampah Plastik Berdasarkan Ukuran pada Sedimen di Beberapa Pantai Kabupaten Pasuruan, Jawa Timur
}

\author{
Defri Yona 1,2, Fadhilah Aisyah di Prikah¹, dan Muhammad Arif As'adi11,3
}

1Program Studi Ilmu Kelautan, Fakultas Perikanan dan Ilmu Kelautan, Universitas Brawijaya, Malang; email: defri.yona@ub.ac.id

${ }^{2}$ Marine Resources Exploration and Management (MEXMA) Research Group, Fakultas Perikanan dan Ilmu Kelautan Universitas Brawijaya, Malang

${ }^{3}$ Coastal Resilience and Climate Change Adaptation - CORECT Research Group, Fakultas Perikanan dan Ilmu Kelautan Universitas Brawijaya, Malang

\begin{abstract}
ABSTRAK
Produksi dan penggunaan plastik yang semakin meningkat dari tahun ke tahun tentunya akan berdampak pada jumlah sampah yang tersebar dan berakhir di laut. Penelitian ini dilakukan di beberapa pantai yang terdapat di Kabupaten Pasuruan yaitu: Pantai Lekok, Pasir Panjang, Watuprapat dan Kapasan. Pemilihan keempat lokasi tersebut dikarenakan masih minimnya pengelolaan sampah plastik serta tingginya aktivitas masyarakat yang berpotensi menimbulkan pencemaran plastik. Penelitian ini bertujuan untuk menganalisis keberadaan plastik berdasarkan ukurannya (makroplastik, mesoplastik dan mikroplastik) serta membandingkan kelimpahan sampah plastik di keempat pantai tersebut. Area sampling makroplastik menggunakan transek kuadran 5 × 5 m dan di dalamnya diletakkan transek kuadran 0,5 x 0,5 m untuk sampling mesoplastik dan mikroplastik. Sampel mikroplastik dilakukan dengan mengambil sedimen sedalam 0-3 cm. Tahap identifikasi makromesoplastik dilakukan secara insitu sedangkan identifikasi mikroplastik dilakukan secara eksitu di laboratorium. Empat jenis sampah plastik ditemukan yaitu film, fiber, fragmen dan styrofoam. Film mendominasi di semua ukuran di keempat pantai yang selanjutnya diikuti oleh fiber, fragmen dan styrofoam. Hal ini dikarenakan tingginya penggunaan plastik sekali pakai seperti kantong plastik, bungkus makanan dan juga alat tangkap ikan. Terdapat perbedaan kelimpahan total sampah plastik di setiap pantai untuk setiap ukuran. Kelimpahan sampah plastik di setiap ukurannya ditemukan lebih besar di Pantai Lekok dan Pasir Panjang dibandingkan di Pantai Watuprapat dan Kapasan. Perbedaan tersebut disebabkan oleh perbedaan tingkat aktivitas manusia di keempat pantai sebagai penyumbang pencemaran plastik.
\end{abstract}

Kata kunci: Kabupaten Pasuruan, Kelimpahan, Makroplastik, Mesoplastik, Mikroplastik

\begin{abstract}
Production level and the use of plastics are increasing from year to year and it will have impact on the amount of plastic wastes in the marine environment. This research was conducted at four beaches in the Pasuruan Regency: Lekok, Pasir Panjang, Watuprapat and Kapasan. The study areas were chosen because of high anthropogenic activities but insufficient treatment of plastic wastes. This study aims to analyze plastic abundances in three different sizes (macro, meso and microplastic) and to compare the total abundances of plastic wastes of the four beaches. Macroplastic samples were collected using a $5 \times 5 \mathrm{~m}$ square transect, while mesoplastic and microplastic samples were acquired using $0.5 \times 0.5 \mathrm{~m}$ square transect placed inside the $5 \times 5$ $\mathrm{m}$ square transect. Microplastic samples were obtained by taking sediment samples as deep as $0-3 \mathrm{~cm}$. Macro-mesoplastic identifications were carried out in-situ while microplastic identification was carried out in the laboratory. Four types of plastic were found: film, fiber, fragment and syrofoam. Film was the most abundant item of the three size categories in all the beaches, followed by fiber, fragment and styrofoam. The high use of disposable plastics such as plastic bags, food wrappers and also fishing gear could explain this result. The abundances of plastic wastes varied among the four study areas for all sizes. Higher total abundances of plastic wastes were found at Lekok dan Pasir Panjang Beach compare to the ones at Watu Prapat and Kapasan Beach. It is likely due to the difference in the level of human activities of the four beaches that lead to plastic pollution.
\end{abstract}

Keywords: Pasuruan Regency, Abundance, Macroplastic, Mesoplastic, Microplastic

Citation: Yona, D., di Prikah, F. A., dan As'adi, M. A (2020). Identifikasi dan Perbandingan Kelimpahan Sampah Plastik Berdasarkan Ukuran pada Sedimen di Beberapa Pantai Kabupaten Pasuruan, Jawa Timur. Jurnal Ilmu Lingkungan, 18(2), 375-383, doi:10.14710/jil.18.2.375-383

\section{Pendahuluan}

Plastik merupakan suatu rangkaian atau ikatan polimer yang tersusun dari unit molekul yaitu monomer (Mujiarto, 2005). Produksi plastik secara masal dimulai sejak tahun 1950 hingga saat ini. Tingkat produksi dan penggunaan plastik yang 
semakin meningkat dari tahun ke tahun berdampak pada jumlah sampah yang tersebar dari lingkungan terestrial, pantai hingga laut terbuka (Barnes dkk., 2009).

Sampah plastik yang memasuki kawasan laut diketahui mencapai 12,7 ton, dimana sebagian besar sampah tersebut bersumber dari aktivitas daratan serta diperkirakan akan terus meningkat sebesar 50250 ton pada tahun 2025 (Jambeck dkk., 2015). Sampah plastik yang tersebar di lautan terbagi menjadi beberapa kategori ukuran yaitu makroplastik $>25 \mathrm{~mm}$, mesoplastik 5-25 mm dan mikroplastik < 5 mm (Gómez dkk., 2018; GESAMP, 2015; Lippiatt dkk., 2013).

Perubahan ukuran sampah plastik terjadi karena proses degradasi yang dapat mengubah polimer plastik. Singh dan Sharma (2008) mengklasifikasikan enam proses degradasi polimer plastik yaitu photooxidative degradation, thermal degradation, ozoneinduced degradation, mechanochemical degradation, catalytic degradation dan biodegradation. Hasil degradasi ini selanjutnya dapat mengakibatkan perubahan bentuk, ukuran maupun warna plastik. Sebagian besar proses degradasi terjadi di lingkungan pantai karena tingginya tingkat paparan sinar matahari, abrasi fisik oleh gelombang, ketersediaan oksigen serta turbulensi (Napper dan Thompson, 2019). Seiring dengan berjalannya waktu partikel makroplastik akan terdegradasi kemudian membentuk retakan, menguning sehingga akan terbagi menjadi partikel mesoplastik dan mikroplastik.

Keberadaan sampah plastik dari berbagai ukuran di perairan laut dapat membahayakan biota laut. Plastik berukuran besar (makro dan mesoplastik) berpotensi menjerat binatang laut yang dapat mengakibatkan luka, kesulitan berenang bahkan kematian (Barboza dkk., 2019; Caron dkk., 2018; Ryan dkk., 2009). Sedangkan, keberadaan mikroplastik di laut berpotensi termakan oleh biota laut mulai dari organisme yang kecil seperti zooplankton hingga ke tropik level yang lebih tinggi (Cole dkk., 2013; Desforges dkk., 2015; Fossi dkk., 2016; Franzellitti dkk., 2019; Li dkk., 2019; Li dkk., 2015; Sarasita dkk., 2020; Wang dkk., 2020).

Penelitian terkait komposisi ukuran sampah plastik telah dilakukan di beberapa lokasi seperti di Sungai Saigon, Vietnam (Lahens dkk., 2018), Kepulauan Maldives, Samudra Hindia (Imhof dkk., 2017), pantai di Korea Selatan (Lee dkk., 2013), pantai rekreasi di Mumbai, India (Jayasiri dkk., 2013) dan sepanjang pantai Portugis (Martins dan Sobral, 2011). Di Indonesia sendiri, tidak banyak publikasi penelitian yang membedakan ukuran sampah plastik, namun terdapat beberapa penelitian yang secara umum menganalisis keberadaan sampah plastik di perairan (Assuyuti dkk., 2018; Djaguna dkk., 2019; Syakti dkk., 2017; Uneputty dan Evans, 1997).

Penelitian ini dilakukan di empat pantai yang terletak di Kabupaten Pasuruan yaitu: Pantai Lekok,
Pantai Pasir Panjang, Pantai Watuprapat dan Pantai Kapasan. Keempat pantai ini termasuk daerah penghasil perikanan yang cukup tinggi dengan mayoritas penduduk bekerja sebagai nelayan dan pedagang (Pemerintah Kabupaten Pasuruan, 2019). Tingginya aktivitas antropogenik yang berasal dari pemukiman penduduk, perkebunan, industri perikanan, pertambakan dan sektor pariwisata di sekitar muara sungai hingga pesisir berpotensi memberi masukan polutan terutama plastik ke dalam lingkungan laut (Ayuningtyas dkk., 2019; Li dkk., 2016; Mauludy dkk., 2019). Rendahnya kesadaran masyarakan dalam pengelolaan sampah mengakibatkan penumpukan sampah plastik di sepanjang pantai-pantai tersebut. Akumulasi sampah plastik secara tidak langsung dapat mempengaruhi hasil perikanan tangkap, ekosistem laut, sektor pariwisata dan kesehatan masyarakat yang ada di pesisir pantai Kabupaten Pasuruan. Oleh karena itu, penelitian ini dilakukan dengan tujuan untuk mengidentifikasi dan menganalisis keberadaan sampah plastik berdasarkan ukurannya serta membandingkan kelimpahannya di keempat pantai tersebut.

\section{Metode Penelitian}

\subsection{Lokasi dan Waktu Penelitian}

Penelitian dilaksanakan di empat pantai di wilayah pesisir Kabupaten Pasuruan yang padat akan aktifitas penduduk mulai dari aktifitas domestik, pariwisata dan perikanan (Gambar 1). Proses identifikasi dan analisis sampel dilakukan di Laboratorium Tanah dan Air Tanah, Teknik Pengairan Universitas Brawijaya dan Laboratorium Eksplorasi Sumberdaya Perikanan dan Kelautan (ESPK) FPIK Universitas Brawijaya.

Pengambilan sampel dilaksanakan di akhir bulan April 2019 selama empat hari dimana sampel diambil saat kondisi surut terendah di area high strandline (Browne dkk., 2010; Ryan dkk., 2009). Prosedur pengambilan sampel di lapang mengacu pada penelitian Lee dkk. (2013) dimulai dari pengukuran panjang garis pantai. Titik sampling di setiap pantai ditentukan dengan membagi panjang garis pantai yang telah didapatkan dengan interval $10 \mathrm{~m}$ untuk peletakan setiap transek kuadrat (Gambar 2). Perbedaan panjang garis pantai menghasilkan jumlah titik sampling yang berbeda-beda di setiap pantai. Pantai Lekok memiliki 17 titik sampling, 6 titik sampling di Pantai Watuprapat dan 7 titik sampling di Pantai Kapasan. Pantai Pasir Panjang karena garis pantai yang cukup panjang maka interval yang digunakan adalah $25 \mathrm{~m}$ sehingga menghasilkan 26 titik sampling.

\subsection{Metode Pengambilan Sampel}

Transek kuadran ukuran 5 X 5 m diletakkan di setiap titik sampling yang digunakan untuk mengumpulkan sample makroplastik. Sampah plastik yang secara visual dapat dikenali diambil dengan 
tangan dengan ukuran maksimal $1 \mathrm{~m}$. Sedimen permukaan sedalam $1 \mathrm{~cm}$ dikumpulkan dengan menggunakan sekop dan disaring menggunakan saringan berukuran $25 \mathrm{~mm}$. Setiap sampah plastik yang tertinggal di atas saringan dikategorikan sebagai makroplastik dan dikumpulkan untuk diindentifikasi lebih lanjut.

Sampel meso dan mikroplastik diambil dari transek berukuran 0,5 X 0,5 m yang diletakan di dalam transek ukuran $5 \times 5 \mathrm{~m}$. Pada transek ini, sedimen sedalam 1-3 cm diambil menggunakan sekop dan disaring menggunakan saringan berukuran $5 \mathrm{~mm}$. Sampah plastik yang tertahan di atas saringan dipisahkan sebagai mesoplastik dan diidentifikasi lebih lanjut. Sebanyak 500 gr sedimen yang lolos saringan $5 \mathrm{~mm}$ dimasukan ke dalam glass jar untuk dianalisis di laboratorium sebagai jenis mikroplastik.

\subsection{Metode Analisis Sampel}

Identifikasi sampel makro dan mesoplastik dilakukan secara visual di laboratorium. Setiap jenis sampel yang ditemukan harus dipastikan berasal dari plastik dan bukan bahan organik yang menyerupai plastik. Plastik dapat dikenali dengan karakternya yang ringan, lentur, mudah disobek namun susah dihancurkan dan juga tidak mengandung unsur bahan organik (Hidalgo-Ruz dkk., 2012; Imhof dkk., 2017). Sampah plastik dikelompokkan ke dalam 4 jenis yaitu fiber, fragmen, film dan styrofoam.

Metode analisis mikroplastik di laboratorium mengacu pada penelitian Dewi dkk., (2015) dan Masura dkk., (2015). Analisis diawali dengan pengeringan sampel sedimen menggunakan oven selama satu malam dengan suhu $90{ }^{\circ} \mathrm{C}$. Sampel yang telah kering selanjutnya ditambahkan $300 \mathrm{ml} \mathrm{NaCl}$ jenuh untuk tahap pemisahan berat jenis sampel sedimen dan mikroplastik. Sampel mikroplastik yang sudah terpisah dari sedimen dipindahkan ke gelas ukur untuk tahap penghancuran bahan organik yang kemungkinan masih ada dalam sampel. Penghancuran bahan organik menggunakan larutan $\mathrm{H}_{2} \mathrm{O}_{2} 30 \%$ dan Fe (II) $0.05 \mathrm{M}$ masing-masing sebanyak $20 \mathrm{ml}$. Sampel didiamkan semalam untuk memisahkan partikel mikroplastik. Selanjutnya identifikasi jenis mikroplastik (fiber, fragmen, film dan stryrofoam) dilakukan menggunakan mikroskop.

Fiber diidentifikasi melalui bentuknya yang memanjang dengan ketebalan yang sama; fragmen adalah partikel dengan bentuk yang tidak beraturan dan tidak bisa dihancurkan menggunakan pinset; film berbentuk lembaran tipis yang biasanya merupakan hancuran dari tas plastik ataupun kemasan makanan; dan styrofoam adalah potongan kecil yang lunak (Dai dkk., 2018; Hidalgo-Ruz dkk., 2012; Mohamed Nor dan Obbard, 2014; Yona dkk., 2019; Zobkov dan Esiukova, 2017).

Seluruh proses penelitian mulai dari sampling di lapang hingga analisis laboratorium diusahakan meminimalisir kontaminasi. Alat-alat yang digunakan dipastikan sudah dibilas dengan aquades tiga kali. Saat analisis laboratorium, sampel selalu dipastikan untuk ditutup dengan alumunium foil jika sedang tidak digunakan untuk menghindari kontaminasi fiber dari udara.

\subsection{Analisis Statistik}

Analisis statistik dilakukan dengan menggunakan Microsoft Excel. Normalitas distribusi data diketahui dengan menggunakan uji normalitas. ANOVA satu arah digunakan untuk mengetahui apakah ada perbedaan rata-rata kelimpahan total sampah plastik antar pantai di setiap ukurannya dan kelimpahan jenis sampah plastik berdasarkan ukurannya disetiap pantai.

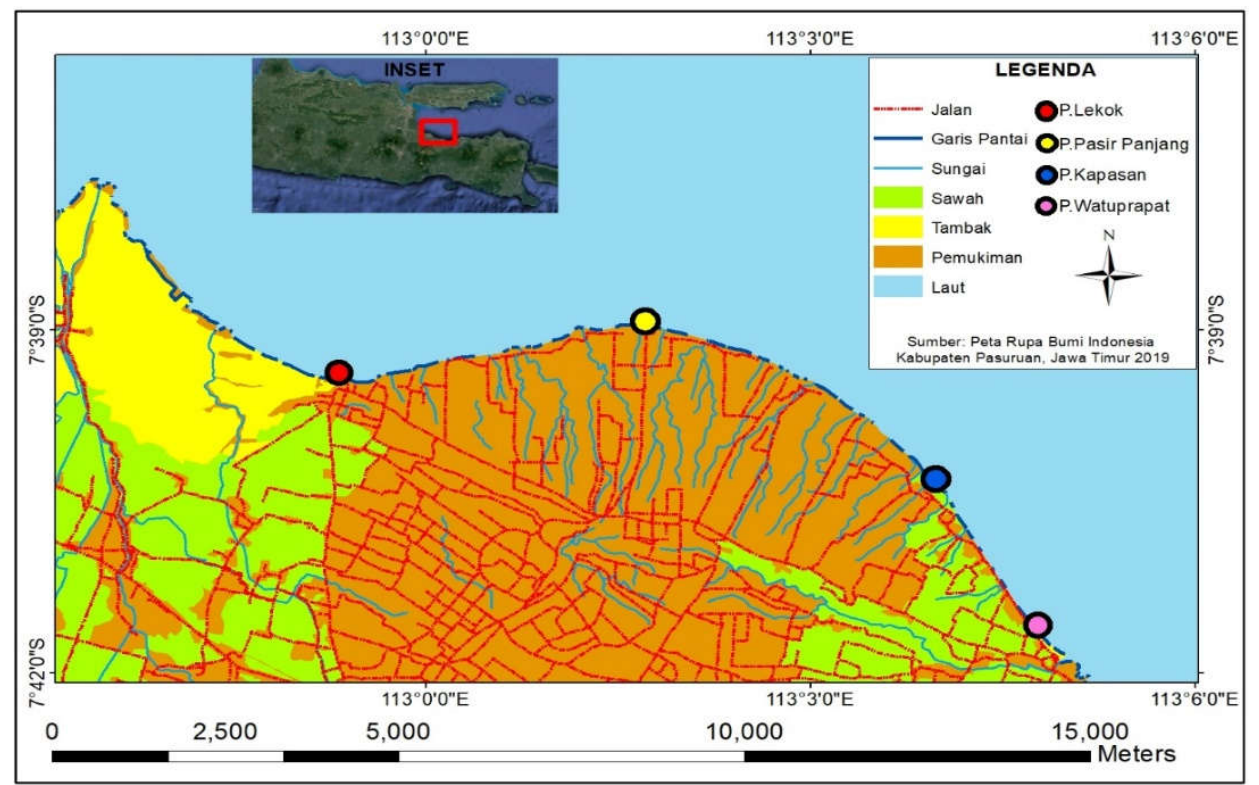

Gambar 1. Lokasi penelitian pada empat pantai di Kabupaten Pasuruan 


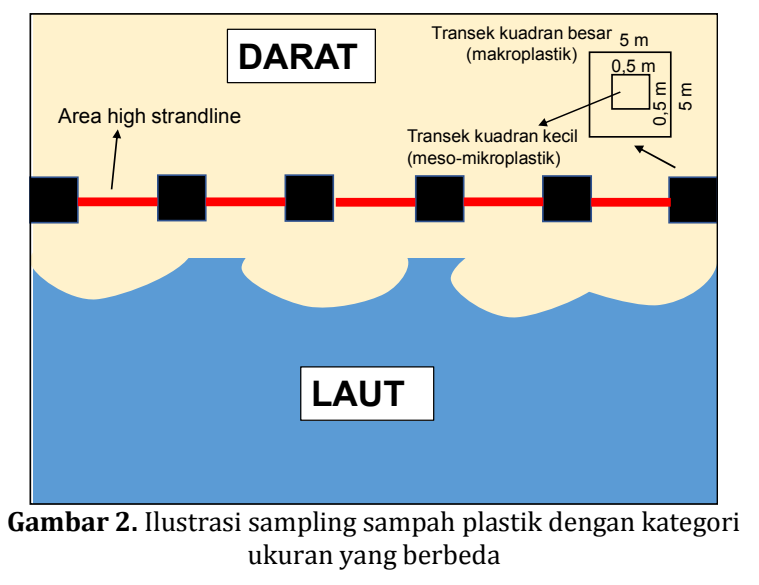

\section{Hasil}

\subsection{Komposisi dan Kelimpahan Total Sampah Plastik di Kabupaten Pasuruan}

Sampah plastik yang menjadi target penelitian ini terdiri dari fiber, film, fragmen dan styrofoam. Keempat jenis sampah tersebut ditemukan dengan persentase yang bervariasi pada setiap ukurannya di empat pantai di pesisir Kabupaten Pasuruan (Gambar 3). Jenis film mendominasi pada semua ukuran dan diikuti oleh fiber, fragmen dan styrofoam. Sebagian besar sampah yang ditemukan pada ukuran makroplastik adalah jenis film (88\%), sedangkan jenis fiber, fragmen dan styrofoam masing-masing ditemukan kurang dari $10 \%$. Pada kategori meso dan mikroplastik, jenis film ditemukan dengan persentase yang tidak jauh berbeda (50 \% untuk mesoplastik dan $42 \%$ untuk mikroplastik) dan diikuti oleh fiber (31\% untuk mesoplastik dan $39 \%$ untuk mikroplastik), fragmen (16\% untuk mesoplastik dan $13 \%$ untuk mikroplastik) dan sedikit styrofoam (2\% untuk mesoplastik dan $7 \%$ untuk mikroplastik). Contoh sampah makroplastik, mesoplastik dan mikroplastik yang ditemukan di keempat pantai diantaranya yaitu kemasan makanan, kantong plastik, kemasan detergen, alat tangkap, gelas plastik dan tutup botol.

Kelimpahan total sampah plastik antar pantai ditemukan berbeda di setiap ukurannya $(\mathrm{p}<0.01)$ (Gambar 4). Kelimpahan sampah ukuran makroplastik tertinggi ditemukan di Pantai Lekok yang diikuti oleh Pantai Pasir Panjang, Kapasan dan Watu Prapat (Gambar 4A). Pada kategori mesoplastik, kelimpahan tertinggi ditemukan di Pantai Pasir Panjang dan diikuti oleh Pantai Lekok, Watu Prapat dan Kapasan (Gambar 4B). Mikroplastik di Pantai Lekok ditemukan lebih tinggi dibandingkan di Pantai Pasir Panjang, Watu Prapat dan Kapasan (Gambar 4C).

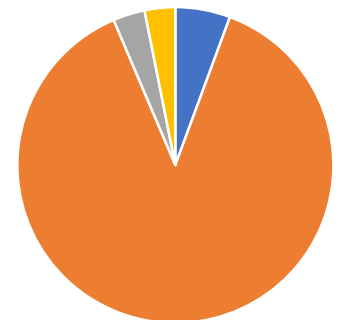

(a) Makroplastik

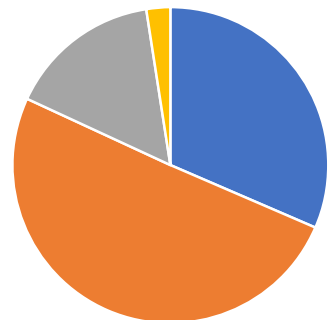

(b) Mesoplastik

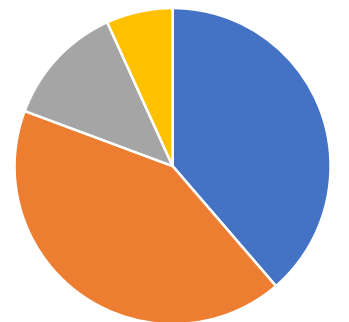

(c) Mikroplastik

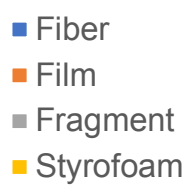

Styrofoam

Gambar 3. Persentase jenis sampah plastik yang ditemukan berdasarkan ukuran (a) makroplastik, (b) mesoplastik dan (c) mikroplastik di empat pantai di Kabupaten Pasuruan
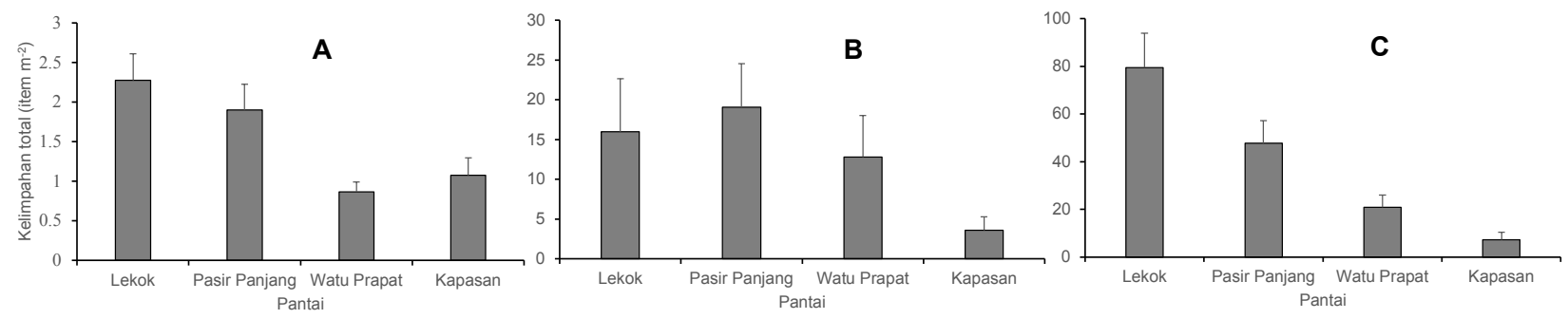

Gambar 4. Kelimpahan total sampah plastik berdasarkan ukurannya (A) makroplastik, (B) mesoplastik dan (C) mikroplastik di empat pantai di Kabupaten Pasuruan

\subsection{Kelimpahan Jenis Sampah Plastik di Setiap Pantai}

\section{A. Pantai Lekok}

Kelimpahan jenis sampah plastik di Pantai Lekok memiliki variasi yang berbeda antar ukurannya $(\mathrm{p}<$ 0,01) (Gambar 5). Untuk kategori makroplastik, jenis film ditemukan empat kali lipat lebih tinggi $\left(2,04 \pm 0,34\right.$ item $\left.\mathrm{m}^{-2}\right)$ dibandingkan jenis fiber, fragmen dan styrofoam yang ditemukan dengan nilai yang sangat rendah. Kelimpahan jenis film juga ditemukan tertinggi pada ukuran mesoplastik $\left(7,76 \pm 3,6\right.$ item $\left.\mathrm{m}^{-2}\right)$ dan diikuti oleh fiber $(4,94 \pm 4,59$ item $\left.\mathrm{m}^{-2}\right)$, fragment $\left(2,35 \pm 2,85\right.$ item $\left.\mathrm{m}^{-2}\right)$ dan styrofoam $\left(0,94 \pm 1,75\right.$ item $\left.\mathrm{m}^{-2}\right)$. Berbeda dengan komposisi pada makro dan mesoplastik, untuk kategori mikroplastik kelimpahan jenis fiber $\left(32,47 \pm 7,99\right.$ item $\left.\mathrm{m}^{-2}\right)$ dan film $\left(32,47 \pm 7,99\right.$ item $\left.\mathrm{m}^{-2}\right)$ ditemukan dengan nilai yang hampir sama dan diikuti oleh fragmen $\left(10,12 \pm 6,18\right.$ item $\left.\mathrm{m}^{-2}\right)$ lalu styrofoam $\left(3,29 \pm 4,30\right.$ item $\left.\mathrm{m}^{-2}\right)$. 


\section{B. Pantai Pasir Panjang}

Variasi kelimpahan jenis kategori makro dan mesoplastik di Pantai Pasir Panjang (Gambar 6A dan 6B) hampir menyerupai pola di Pantai Lekok. Kelimpahan jenis film untuk kategori makroplastik ditemukan mendominasi $\left(1,72 \pm 0,28\right.$ item $\left.\mathrm{m}^{-2}\right)$ dan diikuti oleh kelimpahan jenis fiber, fragmen dan styrofoam yang rendah. Pada kategori mesoplastik, kelimpahan jenis film adalah 8,46 $\pm 3,97$ item $\mathrm{m}^{-2}$ diikuti oleh fiber $\left(7,38 \pm 4,34\right.$ item $\left.\mathrm{m}^{-2}\right)$, fragmen $\left(2,62 \pm 3,57\right.$ item m$\left.^{-2}\right)$ dan styrofoam $((0,62 \pm 1,47$ item $\mathrm{m}^{-2}$ ). Berbeda dengan komposisi makro dan mesoplastik, pada kategori mikroplastik (Gambar 6C) fiber ditemukan dengan kelimpahan tertinggi $\left(23,08 \pm 10,20\right.$ item $\left.\mathrm{m}^{-2}\right)$ dan diikuti oleh film $\left(13,69 \pm 8,33\right.$ item m-2), fragmen $\left(6,62 \pm 6,09\right.$ item $\left.\mathrm{m}^{-2}\right)$ dan styrofoam $\left(4,46 \pm 4,13\right.$ item $\left.\mathrm{m}^{-2}\right)$.

\section{Pantai Watu Prapat}

Kelimpahan jenis film $\left(0,56 \pm 0,31\right.$ item $\left.\mathrm{m}^{-2}\right)$ pada kategori makroplastik di Pantai Watu Prapat ditemukan hampir tiga kali lipat kelimpahan jenis fiber, fragmen dan film (Gambar 7A). Pada kategori mesoplastik (Gambar 7B), jenis film ditemukan sedikit lebih tinggi $\left(6 \pm 3,35\right.$ item $\left.\mathrm{m}^{-2}\right)$ dibandingkan fiber $\left(5,33 \pm 4,13\right.$ item $\left.\mathrm{m}^{-2}\right)$ dan diikuti oleh fragmen $\left(2,67 \pm 2,07\right.$ item $\left.\mathrm{m}^{-2}\right)$. Jenis Styrofoam tidak ditemukan di pantai ini. Berbeda dengan komposisi mikroplastik di Pantai Lekok dan Pantai Pasir Panjang, jenis film di Pantai Watu Prapat untuk kategori mikroplastik (Gambar 7C) ditemukan lebih tinggi $\left(10 \pm 7,04\right.$ item $\left.\mathrm{m}^{-2}\right)$ dibandingkan jenis fiber $\left(6,67 \pm 4,13\right.$ item $\left.\mathrm{m}^{-2}\right)$ dan diikuti oleh fragmen dan styrofoam yang ditemukan dengan kelimpahan hampir sama $\left(2,00 \pm 3,35\right.$ item $\mathrm{m}^{-2}$ untuk fragmen dan $2,00 \pm 2,19$ item $\mathrm{m}^{-2}$ untuk styrofoam).

\section{Pantai Kapasan}

Kelimpahan jenis film di Pantai Kapasan ditemukan mendominasi di semua kategori ukuran (Gambar 8). Film ditemukan dengan kelimpahan 10 kali lipat $(0,95 \pm 0,22$ item $\mathrm{m}-2)$ dibandingkan jenis lainnya untuk makroplastik. Pada kategori mesoplastik, kelimpahan film ditemukan lima kali lipat $\left(9,71 \pm 5,59\right.$ item $\left.\mathrm{m}^{-2}\right)$ jenis fiber dan fragmen. Seperti halnya di Pantai Watu Prapat, jenis styrofoam juga tidak ditemukan di Pantai Kapasan untuk kategori mesoplastik. Selanjutnya, kelimpahan jenis film $\left(18,29 \pm 5,59\right.$ item $\left.\mathrm{m}^{-2}\right)$ untuk ukuran mikroplastik ditemukan hampir tiga kali lipat jenis fiber, fragmen dan styrofoam yang ditemukan dengan kelimpahan yang hampir sama.
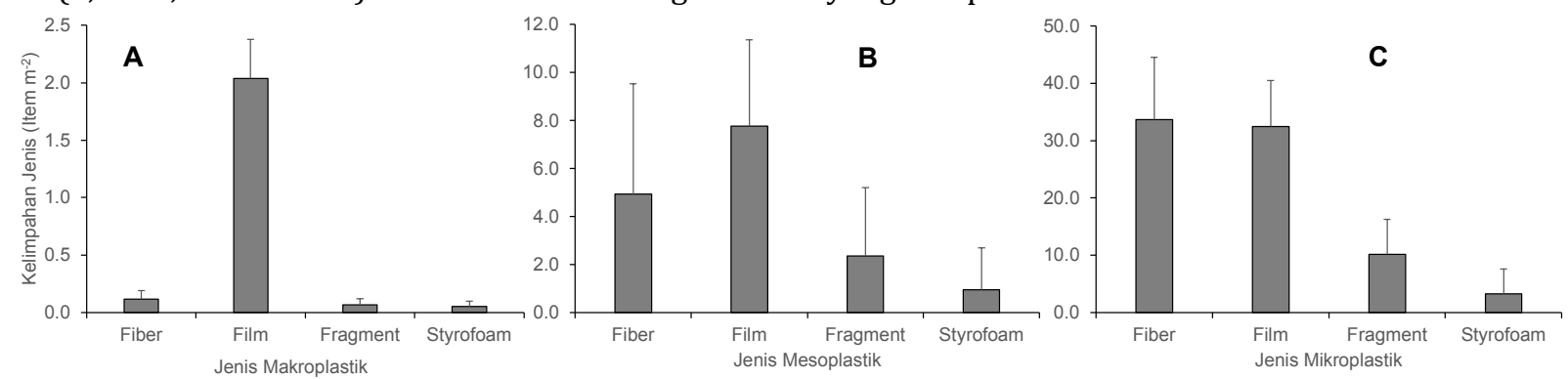

Gambar 5. Rata-rata Kelimpahan Jenis A. Makroplastik, B. Mesoplastik, C. Mikroplastik di Pantai Lekok (n=17)
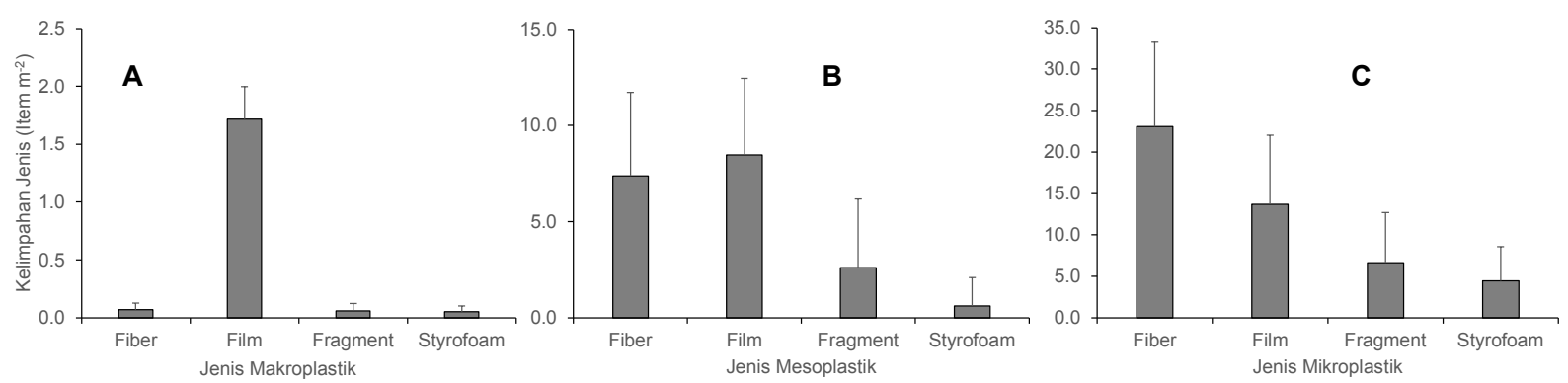

Gambar 6. Rata-rata Kelimpahan Jenis A. Makroplastik, B. Mesoplastik, C. Mikroplastik di Pantai Pasir Panjang (n=26)
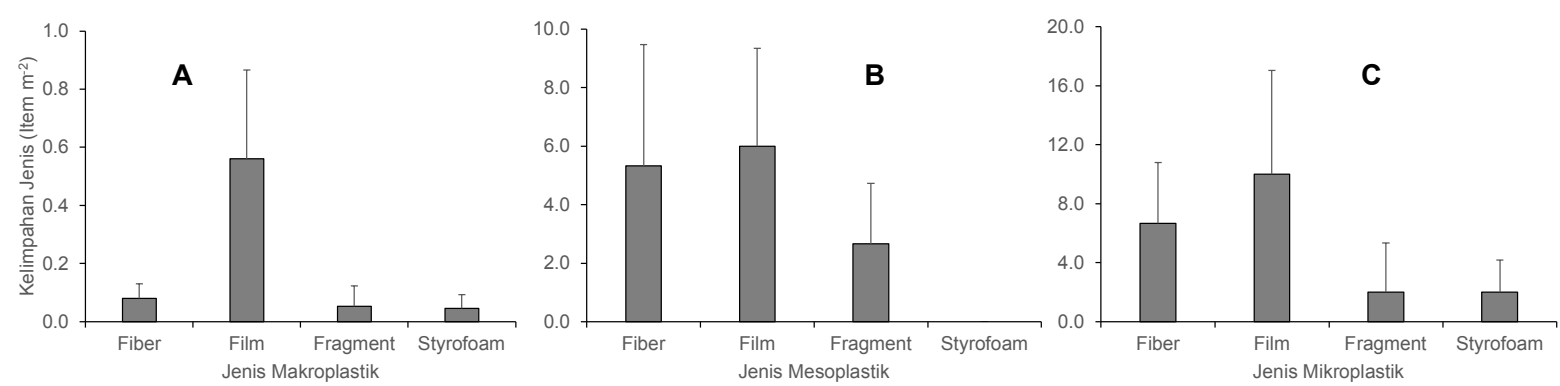

Gambar 7. Rata-rata Kelimpahan Jenis A. Makroplastik, B. Mesoplastik, C. Mikroplastik di Pantai Watu Prapat (n=6) 

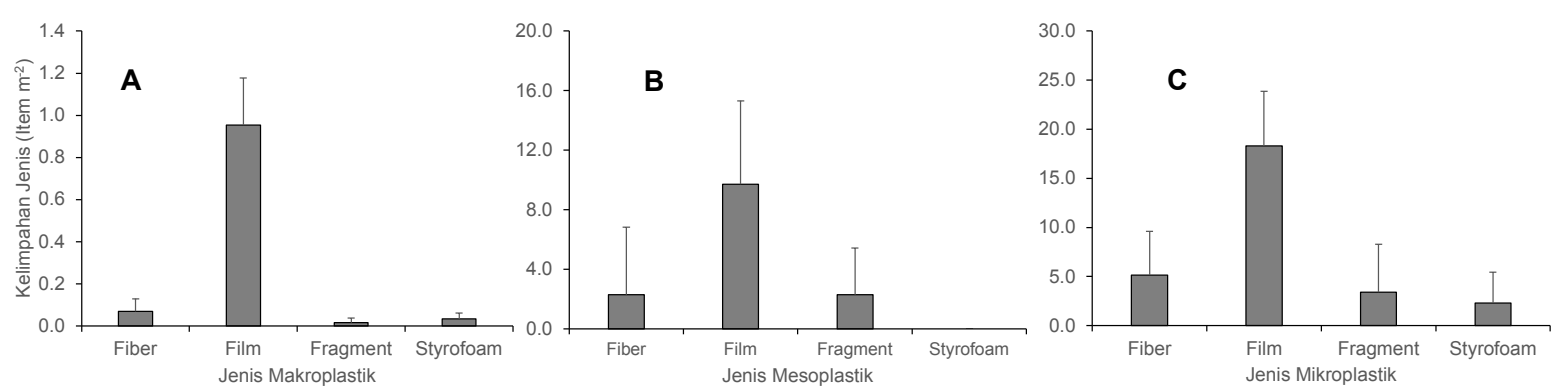

Gambar 8. Rata-rata Kelimpahan Jenis A. Makroplastik, B. Mesoplastik, C. Mikroplastik di Pantai Kapasan (n=7)

\section{Pembahasan}

Hasil penelitian ini menemukan dominansi sampah plastik jenis film di semua ukuran dan pantai. Film adalah jenis plastik yang berasal dari hasil degradasi plastik-plastik kemasan berukuran besar dan ditandai dengan bentuknya yang tidak beraturan dan tipis (Dai dkk., 2018; Mohamed Nor dan Obbard, 2014; Yona dkk., 2019; Zobkov dan Esiukova, 2017). Tingginya penggunaan plastik di masyarakat berpotensi untuk terus meningkatkan keberadaan sampah plastik jenis film di lingkungan. Dominansi film juga ditemukan di beberapa lokasi pantai seperti di northern Lake Victoria (Egessa dkk., 2020), pantai di Teluk Ambon (Manullang, 2019) dan beberapa pantai di Malaysia (Fauziah dkk., 2015).

Film ditemukan dengan persentase paling besar pada ukuran makroplastik. Hal ini diduga dari tingginya masukan sampah-sampah kemasan maupun plastik pembungkus yang berasal dari aktifitas manusia dan tidak dikelola dengan baik. Setelah film, fiber ditemukan dengan persentase yang cukup tinggi terutama pada ukuran meso dan mikroplastik. Sebagian besar penelitian menemukan dominansi fiber maupun fragmen di lingkungan pantai (Álvarez-Hernández dkk., 2019; Bissen dan Chawchai, 2020; Chen dan Chen, 2020; Cordova dkk., 2019; Mauludy dkk., 2019). Hal ini terkait dengan sumber plastik jenis fiber maupun fragmen yang banyak berasal dari aktifitas perikanan seperti jaring dan alat tangkap ikan, aktifitas domestik seperti limbah pencucian pakaian dan juga aktifitas wisata (Browne dkk., 2010; Dowarah dan Devipriya, 2019; Mauludy dkk., 2019; Zhang, 2017). Styrofoam merupakan jenis yang ditemukan dengan persentase paling rendah disemua ukuran. Jenis ini umumnya juga berasal dari aktifitas perikanan seperti penggunaan pelampung (Lee dkk., 2017). De-la-Torre dkk. (2020) menemukan dominansi styrofoam di pantai yang dekat dengan wilayah perkotaan akibat tingginya penggunaan alat makan sekali pakai berbahan styrofoam.

Kelimpahan total sampah plastik berbeda setiap luasan meter persegi daerah penelitian. Mikroplastik ditemukan dengan jumlah paling tinggi dan diikuti oleh meso dan makroplastik (Gambar 4). Hal ini menunjukkan bahwa semakin kecil ukurannya, semakin banyak jumlah yang ditemukan di lingkungan. Degradasi sampah plastik berukuran besar menjadi partikel-partikel yang lebih kecil berperan besar dalam meningkatkan jumlah mikroplastik. Meskipun dalam penelitian ini tidak terdapat hubungan yang signifikan keberadaan sampah plastik berdasarkan ukurannya, namun beberapa penelitian telah menemukan hubungan keberadaan makro, meso dan mikroplastik di perairan pantai (Jeyasanta dkk., 2020; Lee dkk., 2013; Vidyasakar dkk., 2020).

Kelimpahan total sampah plastik berbeda di setiap pantai berdasarkan ukurannya. Sampah plastik ditemukan lebih banyak di Pantai Lekok dan Pasir Panjang dibandingkan di Pantai Watu Prapat dan Kapasan. Perbedaan ini diduga berkaitan dengan kondisi masing-masing pantai dan juga sumber masukan sampah. Pantai Lekok dan Pasir Panjang memiliki garis pantai yang lebih panjang dibandingkan Pantai Watu Prapat dan Kapasan. Selain itu, aktifitas penduduk di kedua pantai ini juga lebih besar dibandingkan Pantai Watu Prapat dan Kapasan. Aktifitas manusia berperan sangat penting dalam menyumbangkan polutan plastik ke lingkungan (Olivatto dkk., 2019).

Kelimpahan jenis sampah disetiap pantai ditemukan dengan pola yang hampir sama terutama untuk kategori makro dan mesoplastik yang didominasi oleh film. Pada kategori mikroplastik, fiber ditemukan paling tinggi dibandingkan ketiga jenis sampah plastik lainnya di Pantai Lekok dan Pasir Panjang. Tingginya aktifitas perikanan di kedua pantai ini menjadi alasan melimpahnya jenis fiber. Fiber dapat berasal dari penggunaan alat tangkap jaring dan tali seperti yang ditemukan pada penelitian Egessa dkk. (2020), Jeyasanta dkk. (2020) dan Dowarah dan Devipriya (2019).

\section{Kesimpulan}

Penelitian ini menemukan bahwa sampah plastik dari ukuran makro, meso dan mikroplastik telah mencemari perairan pantai di Kabupaten Pasuruan. Sampah plastik yang ditemukan didominasi oleh jenis film dan diikuti oleh fiber, fragmen dan styrofoam untuk ketiga macam ukuran. Tingginya penggunaan plastik sebagai pembungkus, aktifitas perikanan dan juga wisata menjadi alasan keberadaan sampah plastik di daerah penelitian. Sampah plastik ditemukan lebih tinggi di Pantai Lekok dan Pasir Panjang dibandingkan di Pantai Watu Prapat dan Kapasan. Kedua pantai ini memiliki aktifitas domestik 
dan perikanan yang lebih besar dibandingkan di Pantai Watu Prapat dan Kapasan. Pengelolaan sampah plastik sangat diperlukan agar pencemaran plastik di lingkungan perairan di Kabupaten Pasuruan dapat dikurangi.

\section{DAFTAR PUSTAKA}

Álvarez-Hernández, C., Cairós, C., López-Darias, J., Mazzetti, E., Hernández-Sánchez, C., González-Sálamo, J., Hernández-Borges, J., 2019. Microplastic debris in beaches of Tenerife (Canary Islands, Spain). Marine Pollution Bulletin. 146, 26-32. https://doi.org/10.1016/j.marpolbul.2019.05.064

Assuyuti, Y.M., Zikrillah, R.B., Tanzil, M.A., Banata, A., Utami, P., 2018. Distribusi dan Jenis Sampah Laut serta Hubungannya terhadap Ekosistem Terumbu Karang Pulau Pramuka, Panggang, Air, dan Kotok Besar di Kepulauan Seribu Jakarta. Majalah Ilmiah Biologi Biosfera. A Scientific Journal. 35, 91-102.

Ayuningtyas, Wulan Cahya., Yona, Defri., S, Syarifah.H.J., Iranawati.F., 2019. Kelimpahan Mikroplastik pada Perairan di Banyuurip, Gresik, Jawa Timur. Journal of Fisheries and Marine Research. 3, 41-45

Barboza, L.G.A., Cózar, A., Gimenez, B.C.G., Barros, T.L., Kershaw, P.J., Guilhermino, L., 2019. Chapter 17 Macroplastics Pollution in the Marine Environment, in: Sheppard, C. (Ed.), World Seas: An Environmental Evaluation (Second Edition). Academic Press, pp. 305328. https://doi.org/10.1016/B978-0-12-805052$1.00019-\mathrm{X}$

Barnes, D.K.A., Francois, G., Richard C. Thompson, Morton Barlaz. 2009. Accumulation and Fragmentation of Plastic Debris in Global Environments. Philosophical Transactions of The Royal Society B. 364,1985-1998. https:// doi.org /10.1098/rstb. 2008.0205

Bissen, R., Chawchai, S., 2020. Microplastics on beaches along the eastern Gulf of Thailand-A preliminary study. Marine Pollution Bulletin. 157, 111345. https://doi.org/10.1016/j.marpolbul.2020.111345

Browne, M.A., Phillip Crump, Stewart J. Niven, Emma Teuten, Andrew Tonkin, Tamara Galloway, Richard Thompson. 2011. Accumulation of Microplastic on The Shorelines Worldwide: Source and Sinks. Environtmental Science \& Technology. 45, 9175-9179. https://doi.org/10. 1021/es201811s

Browne, M.A., Galloway, T.S., Thompson, R.C., 2010. Spatial Patterns of Plastic Debris along Estuarine Shorelines. Environmental Science and Technology. 44, 34043409. https://doi.org/10.1021/es903784e

Cole, M., Lindeque, P., Fileman, E., Halsband, C., Goodhead, R., Moger, J., \& Galloway, T. S. 2013. Microplastic Ingestion by Zooplankton. Environmental Science \& Technology, 47(12), 6646-6655. doi:10.1021/es400663f

Caron, A. G. M., Thomas, C. R., Berry, K. L. E., Motti, C. A., Ariel, E., \& Brodie, J. E. (2018). Ingestion of microplastic debris by green sea turtles (Chelonia mydas ) in the Great Barrier Reef: Validation of a sequential extraction protocol. Marine Pollution Bulletin. 127, 743-751. doi:10.1016/j.marpolbul.2017.12.062

Chen, M.-C., Chen, T.-H., 2020. Spatial and seasonal distribution of microplastics on sandy beaches along the coast of the Hengchun Peninsula, Taiwan. Marine Pollution Bulletin. 151, 110861. https://doi.org/10.1016/j.marpolbul.2019.110861
Cordova, M.R., Purwiyanto, A.I.S., Suteja, Y., 2019. Abundance and characteristics of microplastics in the northern coastal waters of Surabaya, Indonesia. Marine Pollution Bulletin. 142, 183-188. https://doi.org/10.1016/j.marpolbul.2019.03.040

Dai, Z., Haibo Zhang, Qian Zhou, Tao Chen, Chuancheng Fu, Yongming Luo. 2018. Occurrence of Microplastics in The Water Column and Sediment in an Inland Sea Affected by Intensive Anthropogenic Activities. Environmental Pollution. 11435. https://doi.org/10.1016/j. envpol.2018. 07.131

Desforges, J.-P.W., Galbraith, M., Ross, P.S., 2015. Ingestion of Microplastics by Zooplankton in the Northeast Pacific Ocean. Archive of Environmental Contamination and Toxicology. 69 , 320-330. https://doi.org/10.1007/s00244-015-0172-5

De-la-Torre, G.E., Dioses-Salinas, D.C., Castro, J.M., Antay, R., Fernández, N.Y., Espinoza-Morriberón, D., SaldañaSerrano, M., 2020. Abundance and distribution of microplastics on sandy beaches of Lima, Peru. Marine Pollution Bulletin. 151, 110877. https://doi.org/10.1016/j.marpolbul.2019.110877

Djaguna, A., Pelle, W.E., Schaduw, J.N., Manengkey, H.W., Rumampuk, N.D., Ngangi, E.L., 2019. Identifikasi sampah laut di Pantai Tongkaina dan Talawaan Bajo. Jurnal Pesisir Dan Laut Tropis. 7, 174-182. https://doi.org/10.35800/jplt.7.3.2019.24432

Dewi, I.S., Budiarsa, A.A., Irwan, R.R. 2015. Distribusi Mikroplastik pada Sedimen di Muara Badak, Kabupaten Kutai Kartanegara. DEPIK 4, 121-131. https://doi.org/10.13170/depik.4.3.2888

Dowarah, K., Devipriya, S.P., 2019. Microplastic prevalence in the beaches of Puducherry, India and its correlation with fishing and tourism/recreational activities. Marine Pollution Bulletin. 148, 123-133. https://doi.org/10.1016/j.marpolbul.2019.07.066

Egessa, R., Nankabirwa, A., Basooma, R., Nabwire, R., 2020. Occurrence, distribution and size relationships of plastic debris along shores and sediment of northern Lake Victoria. Environmental Pollution. 257, 113442. https://doi.org/10.1016/j.envpol.2019.11344

Fauziah, S., Liyana, I., Agamuthu, P., 2015. Plastic debris in the coastal environment: The invincible threat? Abundance of buried plastic debris on Malaysian beaches. Waste Management and Research. 33, 812821. https://doi.org/10.1177/0734242X15588587

Fossi, M.C., Marsili, L., Baini, M., Giannetti, M., Coppola, D., Guarranti, C., Caliani, I., Minutoli, R., Lauriano, G., Finoia, M.G., Rubegni, F., Panigada, S., Bérubé, M., Ramirez, J.U., Panti, C. 2016. Fin whales and microplastics: the Mediterranean Sea and the sea of Cortez scenarios. Environmental Pollution. 209, 68-78. doi:10.1016/j.envpol.2015.11.022

Franzellitti, S., Canesi, L., Auguste, M., Wathsala, R.H.G.R., Fabbri, E., 2019. Microplastic exposure and effects in aquatic organisms: A physiological perspective. Environmental Toxicology and Pharmacology. 68, 3751. https://doi.org/10.1016/j.etap.2019.03.009

GESAMP, 2015. "Sources, fate and effects of microplastics in the marine environment: a global assessment" (Kershaw, P. J., ed.). (IMO/FAO/UNESCOIOC/UNIDO/WMO/IAEA/UN/UNEP/UNDP Joint Group of Experts on the Scientific Aspects of Marine Environmental Protection). Rep. Stud. GESAMP No. 90, $96 \mathrm{p}$.

Gómez, P.V., Cornell, S.E., Fabres, J. 2018. Marine Plastic Pollution as a Planetary Boundary Threat - The 
Drifting Piece in The Sustainability Puzzle. Marine Policy. 96, 213-220. https://doi.org/10. 1016/j.marpol.2017.11.035

Hidalgo-Ruz, V., Gutow, L., Thompson, R.C., Thiel, M., 2012. Microplastics in the Marine Environment: A Review of the Methods Used for Identification and Quantification. Environmental Science and Technology. 46, 30603075. https://doi.org/10.1021/es2031505

Imhof, H.K., Sigl, R., Brauer, E., Feyl, S., Giesemann, P., Klink, S., Leupolz, K., Löder, M.G.J., Löschel, L.A., Missun, J., Muszynski, S., Ramsperger, A.F.R.M., Schrank, I., Speck, S., Steibl, S., Trotter, B., Winter, I., Laforsch, C., 2017. Spatial and temporal variation of macro-, meso- and microplastic abundance on a remote coral island of the Maldives, Indian Ocean. Marine Pollution Bulletin. 116, 340-347. https://doi.org/10.1016/j.marpolbul.2017.01.010

Jambeck, J.R., Geyer, R., Wilcox, C., Siegler, T.R., Perryman, M., Andrady, A., Narayan, R., Law, K.L. 2015. Plastic waste inputs from land into the ocean. Science. AAAS 347, 768-771

Jayasiri, H.B., Purushothaman, C.S., Vennila, A., 2013. Quantitative analysis of plastic debris on recreational beaches in Mumbai, India. Marine Pollution Bulletin. 77 , 107-112. https://doi.org/10.1016/j.marpolbul.2013.10.024

Jeyasanta, K.I., Sathish, N., Patterson, J., Edward, J.K.P., 2020. Macro-, meso- and microplastic debris in the beaches of Tuticorin district, Southeast coast of India. Marine Pollution Bulletin. 154, 111055. https://doi.org/10.1016/j.marpolbul.2020.111055

Lahens, L., Strady, E., Kieu-Le, T.-C., Dris, R., Boukerma, K., Rinnert, E., Gasperi, J., Tassin, B., 2018. Macroplastic and microplastic contamination assessment of a tropical river (Saigon River, Vietnam) transversed by a developing megacity. Environmental Pollution. 236, 661-671. https://doi.org/10.1016/j.envpol.2018.02.005

Lee, J., Hong, S., Song, Y.K., Hong, S.H., Jang, Y.C., Jang, M., Heo, N.W., Han, G.M., Lee, M.J., Kang, D., Shim, W.J., 2013. Relationships among the abundances of plastic debris in different size classes on beaches in South Korea. Marine Pollution Bulletin. 77, 349-354. https://doi.org/10.1016/j.marpolbul.2013.08.013

Lee, Jongsu, Lee, Jongmyoung, Hong, S., Hong, S.H., Shim, W.J., Eo, S. 2017. Characteristics of Meso-Sized Plastic Marine Debris on 20 Beaches in Korea. Marine Pollution Bulletin. 123, 92-96. https://doi.org/10.1016/j.marpolbul.2017.09.020

Li, J., Lusher, A.L., Rotchell, J.M., Deudero, S., Turra, A., Bråte, I.L.N., Sun, C., Shahadat Hossain, M., Li, Q., Kolandhasamy, P., Shi, H., 2019. Using mussel as a global bioindicator of coastal microplastic pollution. Environmental Pollution. 244, 522-533. https://doi.org/10.1016/j.envpol.2018.10.032

Li, W.C., Tse, H.F., Fok, L., 2016. Plastic waste in the marine environment: A review of sources, occurrence and effects. Science of the Total Environment. 566-567, 333-349.

https://doi.org/10.1016/j.scitotenv.2016.05.084

Li, J., Yang, Dongqi., Jabeen, Khalida., Shi, Huahong. 2015. Microplastics in commercial bivalves from China. Environmental Pollution. 207, 190-195. http://dx.doi.org/10.1016/j.envpol.2015.09.018

Lippiatt, S., Sarah Opfer, Courtney Arthur. 2013. Marine Debris Monitoring and Assessment: Recommendations for Monitoring Debris Trends in the Marine Environment. NOAA Tech. Memo. NOS-OR \& R-46, 77.

Manullang, C.Y., 2019. The abundance of Plastic Marine Debris on Beaches in Ambon Bay. IOP Conf. Ser. Earth Environ. Sci. 253, 012037. https://doi.org/10.1088/1755-1315/253/1/012037

Martins, J., Sobral, P. 2011. Plastic Marine Debris on The Portuguese Coastline: A Matter of Size?. Marine Pollution Bulletin. 62, 2649-2653. https://doi.org/10.1016/j.marpolbul.2011.09.028

Masura, B., Gregory Foster, Courtney Arthur. 2015. Laboratory Methods for the Analysis of Microplastics in the Marine Environment. NOAA Tech. Memo. NOSOR \& R-48, 39

Mauludy, M.S., Yunanto, A., Yona, D., 2019. Microplastic Abundances in the Sediment of Coastal Beaches in Badung, Bali. Jurnal Perikanan Universitas Gadjah Mada 21, 73-78. https://doi.org/10.22146/jfs.45871

Mohamed Nor, N.H., Obbard, J.P. 2014. Microplastics in Singapore's Coastal Mangrove Ecosystems. Marine Pollution Bulletin. 79, 278-283. https://doi.org/10. 1016/j. marpolbul.2013.11. 025

Mujiarto, I. 2005. Sifat dan Karakteristik Material Plastik dan Bahan Aditif. Traksi 3, 9

Napper, I.E., Thompson, R.C. 2019. Micro- and Macroplastics in Aquatic Ecosystems, in: Encyclopedia of Ecology. Elsevier, pp. 116-125. https://doi.org/10.1016/B978-0-12-4095489.10600-1

Olivatto, G.P., Martins, M.C.T., Montagner, C.C., Henry, T.B., Carreira, R.S., 2019. Microplastic Contamination in Surface Waters in Guanabara Bay, Rio de Janeiro, Brazil. Marine Pollution Bulletin. 139, 157-162. https://doi.org/10.1016/j.marpolbul.2018.12.042

Pemerintah Kabupaten Pasuruan. 2019. https://www.pasuruankab.go.id/pages-1-gamb aranumum.html (accessed 18.03.2019)

Ryan, P.G., Moore, C.J., van Franeker, J.A., Moloney, C.L., 2009. Monitoring the abundance of plastic debris in the marine environment. Philosophical Transactions of the Royal Society B: Biological Science. 364, 19992012. https://doi.org/10.1098/rstb.2008.0207

Sarasita, D., Yunanto, A., Yona, D., 2020. Kandungan mikroplastik pada empat jenis ikan ekonomis penting di perairan Selat Bali. Jurnal Iktiologi Indonesia. 20, 112. https://doi.org/10.32491/jii.v20i1.508

Singh, B., Sharma, N., 2008. Mechanistic implications of plastic degradation. Polymer Degradation and Stability. 93, 561-584. https://doi.org/10.1016/j.polymdegradstab.2007.11. 008

Syakti, A.D., Bouhroum, R., Hidayati, N.V., Koenawan, C.J., Boulkamh, A., Sulistyo, I., Lebarillier, S., Akhlus, S., Doumenq, P., Wong-Wah-Chung, P., 2017. Beach macro-litter monitoring and floating microplastic in a coastal area of Indonesia. Marine Pollution Bulletin. 122 , 217-225. https://doi.org/10.1016/j.marpolbul.2017.06.046

Uneputty, P.A., Evans, S.M., 1997. Accumulation of beach litter on islands of the Pulau Seribu Archipelago, Indonesia. Marine Pollution Bulletin. 34, 652-655. https://doi.org/10.1016/S0025-326X(97)00006-4

Vidyasakar, A., Krishnakumar, S., Kasilingam, K., Neelavannan, K., Bharathi, V.A., Godson, P.S., Prabha, K., Magesh, N.S., 2020. Characterization and distribution of microplastics and plastic debris along 
Silver Beach, Southern India. Marine Pollution Bulletin. 158, 111421. https://doi.org/10.1016/j.marpolbul.2020.111421

Wang, W., Ge, J., Yu, X., 2020. Bioavailability and toxicity of microplastics to fish species: A review. Ecotoxicology and Environmental Safety. 189, 109913. https://doi.org/10.1016/j.ecoenv.2019.109913

Yona, D., Syarifah Hikmah Julinda Sari, Feni Iranawati, Syamsul Bachri, Wulan Cahya Ayuningtyas. 2019. Microplastics in The Surface Sediments From The
Eastern Waters of Java Sea, Indonesa. ICTROPS 2018, F1000 Research 8, 1-8. https://doi.org/10.12688/f1000research.17103.1

Zhang, H., 2017. Transport of microplastics in coastal seas. Estuarine and Coastal Shelf Sciences. 199, 74-86. https://doi.org/10.1016/j.ecss.2017.09.032

Zobkov, M., Esiukova, E., 2017. Microplastics in Baltic bottom sediments: Quantification procedures and first results. Marine Pollution Bulletin. 114, 724-732. https://doi.org/10.1016/j.marpolbul.2016.10.060 